\title{
The Relationship Between Money Supply and Real Effective Exchange Rate Fluctuations in Kenya
}

\author{
Abung'ana Geoffrey Ligare $^{1^{*}} \quad$ Destaings Nyongesa ${ }^{2} \quad$ Nelson Obange $^{3}$ \\ School of Business and Economics, Maseno University, P O Box Private Bag, Maseno
}

\begin{abstract}
Exchange rates play an important role in economic growth especially through foreign trade. Exchange rates in Kenya have been experiencing fluctuations since the transition of the fixed exchange rate regime of the 1960s to the crawling peg of the 1970s to 1980s and lately the floating exchange rate of the 1990s to date. The exchange rate has oscillated between Kshs. 7.142 in 1960s to Kshs. 102.35 per unit US dollar in 2015. The magnitude of exchange rate fluctuations in most developing economies has attracted the interest of many scholars including economists and policy makers. These scholars have however differed on the determinants of real effective exchange rate fluctuations and their respective levels of significance. The purpose of this study therefore was to examine the relationship between money supply and real effective exchange rate fluctuations in Kenya. External debt, trade balance and inflation rate were used as the intervening variables. The study was anchored on the balance of payments theory of exchange rate determination. The study used annual time series data for the period (19722015). The study used correlational study design and it employed the stationarity tests, cointegration and ECM. The study concluded that there exists a positive significant relationship between money supply, trade balance, inflation rate and real effective exchange rate fluctuations in Kenya. An increase in money supply also leads to depreciation in the Kenyan shilling same to an increasing inflation rate. An increasing debt burden depreciates the Kenyan shilling. These results are in conformity with the balance of payments theory of exchange rate determination. The study recommends that policy makers should formulate sound credit control policies to control money supply in the economy.
\end{abstract}

Keywords: Money supply, exchange rate, trade balance, external debt, inflation rate, Kenya

DOI: $10.7176 / \mathrm{JESD} / 10-12-14$

Publication date:June $30^{\text {th }} 2019$

\section{Introduction}

An exchange rate is defined as a price at which one currency may be converted into another. The Real effective exchange Rate is defined as the rate at which goods, and services produced within an economy can be exchanged for those produced in another country or group of countries abroad (Musyoki, Pokhariyal \& Pundo, 2012). According to the World Bank (2013) real effective exchange rates are nominal exchange rate that has been adjusted for the different rates of inflation between Kenya shillings and a foreign currency. In practice, changes of the real effective exchange rate rather than its absolute level are important. An increase in the real effective exchange rate is termed appreciation while a decrease is depreciation. This study will adopt an official exchange rate defined by the WorldBank, 2015; official exchange rate refers to the exchange rate determined by national authorities or to the rate determined in the legally sanctioned exchange market. It is calculated as an annual average based on monthly averages (local currency units relative to the U.S. dollar).

Otuori (2013) observed that exchange rates in Kenya had been fluctuating over years with a rising trend; the exchange rate for the US dollar was 63.3 in 2007, 78.0 in 2008, 75.4 in 2009, 80.6 in 2010 and 80.6 in 2011. This showed a weakening shilling from 2007 to 2011 which may have been caused by a number of factors such as interest rates, inflation rates, terms of trade, and public debt. However, no empirical study has been done to evaluate the relationship between money supply, external debt, trade balance, inflation and real effective exchange rate in Kenya.

Most scholars have studied the effect of exchange rate on money supply and ignored the fact that an increase or a decrease in money supply in the economy also affects the direction of the exchange rate. It is also evident from the emperical studies analysed (Mussa,1984; Hopper,1997; Ndungu,2000; Karanja,2010; Saeed,2012) that the few scholars that have studied the effect of money supply on exchange rate were not aggreing on the level of significance of money supply and exchange rate fluctuations and their relationship; some were showing negative (Musa, 1984, Hopper,1997, Ndung'u, 2000) while others positive (Saeed et al.,2012) results; some were showing significant (Hopper,1997, Ndung'u, 2000, Saeed et al., 2012) while others insignificant (Mussa,1984) relationships. Due to lack of consensus by various scholars on contribution of money supply on real effective exchange rate fluctuations and the limited sample sizes used by the scholars, this study aimed to determine the relationship between money supply and real effective exchange rate fluctuations in kenya both in the short run and long run periods using a relatively larger sample size from 1972 to 2015 . The remainder of this article paper is organized as follows. Section 2 covers review of past studies and defines the main hypothesis. Section 3 covers materials and methods. Section 4 covers the results and discussion. Section 5 presents the conclusion and section 
6 covers the recommendations.

\section{Literature Review}

\subsection{Theoretical Framework}

This study reviewed the balance of payments theory so as to put Money Supply into perspective.

\subsubsection{The Balance of Payments Theory}

The balance of payments theory asserts that the consistent adverse balance of payment will make the currency to depreciate in near future and the consistent surplus in balance of payment will make the currency appreciate in near future. Forecasting future exchange rates is virtually necessity for a multinational enterprise, inter-alia, to develop an international financial policy. It is particularly useful for a foreign country if it intends to borrow from or invest. Forward rates are likely to be an unbiased predictor of the future spot rate. In other words, the rate of premium or discount should be an unbiased predictor of the rate of appreciation or depreciation of a currency (Edward, 1994). Miller (1986) has shown that in a four good (Tradables T, Nontradables N, Bonds A, Money M) model, that the sum of the period analysis, effective demand and supply budget constraint for the household, business and government sector of an economy lead to the aggregate budget constraint:

$E_{T}+E_{N}+E_{A}+E_{M} \equiv 0$

Where, ${ }^{E_{i}}$ represent the ex ante domestic supply minus demand for that good; domestic excess supply of good $i$ for a closed economy. But for an open economy we take account of foreign transactions denoted by $X_{i}$-excess supply of each good. By definition of $\mathrm{N}$, it follows that $X_{N}=E_{N}$. By assumption here, home residents had only home money and no home money is held abroad. Thus $X_{M}=E_{M}$. The $E_{T}$ term represents the output minus total domestic demand of T. Hence it follows that:

$X_{T}=E_{T}-B_{T}$

Where, $X_{T}$ is excess total market supply of home tradables, $B_{T}$ Ii ex ante balance of trade.

A similar definition applies to market excess of bonds, that is:

$X_{A}=E_{A}-K_{F}$

Where, $K_{F}$ ex ante net international flow

With equation 2.1 and these definitions Miller (1986) obtains the identity:

$X_{T}+X_{N}+X_{A}+X_{M}=-B P$

Where,

$B P=B_{T}+K_{F}=$ The ex ante balance of payments

Identity 2.2 has some intuitive appeal if we define ex ante balance of payments as excess supply of foreign exchange $X_{F X}$. Then 2.2 can be written as:

$X_{T}+X_{N}+X_{A}+X_{M}+X_{F X}=0$

The sum of excess supplies in all markets is always zero.

From equation 2.3 the first four items equal to $-\mathrm{BP}$. Therefore, equation 2.3 can also be written as:

$-B P+X_{F X}=0$ And thus

$X_{F X}=B P$ We can therefore say

$X_{F X}=f(B P)$

From equation 2.2 equation 2.4 becomes,

$$
X_{F X}=f\left(X_{T}, X_{N}, X_{A}, X_{M}\right)
$$

\subsection{Money Supply and Real effective exchange Rate Fluctuations}

Hopper (1997) reviewed exchange-rate economics, focusing on what is predictable and what wasn't. The monetary model focused on the demand and supply of money. If the money supply in the United States rose, but nothing else changed, the average level of prices in the United States tend to rise. Since the price level in the foreign country remains fixed, more dollars were needed to get one unit of foreign currency. Hence, the dollar price of the foreign currency rose; the dollar depreciated. According to Saeed et al. (2012), there was a strong positive relation 
between the ratio of the money stock of pakistan relative to the US dollar. The data range used was from 1990 to 2010 annual data representing 21 years. This researcher generally used a small sample size for time series analysis as it is prone to give unreliable results for prediction. A relatively larger sample was used in the current study to address this shortfall.

Papadopoulos and Zis (2000) studied the determination of exchange rate in Greece by estimating Drachma/ECU rate employing co-integration technique, Impulse response and Variance decomposition analysis using monthly data from 1980 to 1991. Exchange rate variation appears to be dominated mainly by money supply. However, this study did not give the long run effect of the money supply variable on exchange rate variation. To fill this gap, the current study sought to analyze the long run relationship of money supply and exchange rate fluctuations in Kenya for prediction purposes. Wilson (2009) concluded that in the US, money supply was positively related to the effective real effective exchange rate and that increasing money causes depreciation in the value of currency.

Karanja (2010) did a study on determinants of exchange rate and exchange rate fluctuations on selected countries using monthly data for the period 1993 to 2008 with an OLS method of analysis. It was concluded that in Kenya and Singapore there was a negative but significant relationship between money supply and exchange rate fluctuations. This was contrary to the UK where a positive and insignificant relationship was found. The method of OLS gives an association between variables. However, the method did not link the short run dynamics to the long run relations hence one may not be able to use it for prediction and policy recommendations. Hence, the current study sought to employ both cointegration and the ECM which gives better analysis both in the short run and long run.

Ndungu (2000) analyzed the relationships among money supply, real effective exchange rate movements, domestic rate of inflation, and the government share of domestic credit. The study was based on annual 25 years' time series data from 1970 to 1995 . The analysis suggested that money supply drove real effective exchange rate movements, and real effective exchange rate movements have an impact on money supply. Excess money supply has feedback effects with real effective exchange rate. Money supply growth depreciates the exchange rate. Despite analyzing the data both in the short run and long run, Ndung'u used a relatively smaller sample size of 25 years which is likely to suffer from time biasedness and hence may give biased results. To address this pitfall, the current study sought to use a relatively larger sample size to examine the effect of money supply on real effective exchange rate fluctuations in Kenya using cointegration and ECM.

In his study using 15 years data, Mussa (1984), established that in the US money supply had a negative but insignificant impact on exchange rate fluctuations. Hopper (1997), carried out a similar study in the US using 25 years data from 1980 to 1995 and found out that there was a negative but significant relationship between money supply and exchange rate. A rise in money supply depreciated the local currency. In his study Ndungu (2000), observed that in kenya money supply had a negative but significant impact on echange rate; cornforming to the results by Hopper (1997) but contradicting Mussa (1984). The most recent study by Saeed et al. (2012), showed that there was a positive but significant relationship between money supply and exchange rate fluctuations in Pakistan; a rise in money supply appreciated the Pakistani rupee. The literature reviewed above led to the following hypothesis statement:

\section{$H_{0}:$ There is no relationship between money supply and real effective exchange rate fluctuations in Kenya}

\subsection{Materials and Methods}

This study used correlational research design and it adopted a linear regression model relating the exchange rate fluctuations (dependent variable) as a function of money supply, external debt, trade balance and inflation rate (independent variables) by modifying model 2.5 such that:

$$
\begin{aligned}
& X_{F X}=f\left(X_{T}, X_{N}, X_{A}, X_{M}\right)_{\text {became }} \\
& E=f(M, E D, T B, I)
\end{aligned}
$$

Where,

E is real effective exchange rate fluctuations, $M$ is money supply, in this study M3 is used to mean money supply, ED is external debt, TB is trade balance and I is inflation rate.

Based on the classical linear regression model this study assumed a linear model which took the following form: $E_{t}=\beta_{0}+\beta_{1} M_{t}+\beta_{2} E D_{t}+\beta_{3} T B_{t}+\beta_{4} I_{t}+\varepsilon_{t}$

Where, $\varepsilon \quad$ Stochastic Term/ error term; $\varepsilon \sim N\left(0, \sigma^{2}\right)$ i.e., the error term is normally distributed with a zero mean and constant variance, $\beta_{0}$ Constant and $\beta_{1,2,3,4}$ are coefficients to be estimated. They measure the responsiveness of the dependent variable to changes in the independent variables. 
The target population was all the macroeconomic determinants of real effective exchange rate fluctuations. The study focused on money supply as a determinants of real effective exchange rate. External debt, trade balance and inflation rate were treated as intervening variables. The study focused on the period 1972-2015. This was the period that kenya shifted from the initial fixed exchange rate regim to the crawling peg to cushion the country against the adverse effects of the 1970s oil price shocks that were threatening the growth of the country. During this period the country also experienced the highest depreciation of the shilling in the year 2015 . This study used time series secondary data for the period 1972 to 2015 . The study employed inferential data analysis techniques which included correlation analysis, unit root tests, co-integration test and the error correction model. Diagnostic tests which include heteroscedasticity, autocorrelation, normality test and multicollinearity were carried out and the results presented in form of tables. Stationary tests was done using the Augmented Dickey Fuller test and confirmed by the Phillips-pheron (pp) unit root tests.

$$
\Delta X_{t}=\delta X_{t-1}+\varepsilon_{t}
$$

Where equation 3.3 is the first difference operator and $\mathrm{X}$ represents any of the variables. The following hypotheses will be tested:

$H_{0}: \delta=0$ that is, unit root exists (time series is non stationary)

$H_{1}:<0 \quad$ time series is stationary

This was done using ADF test as shown below:

$$
\begin{aligned}
& \Delta X_{t}=\delta X_{t-1}+\sum_{i=1}^{m} \alpha_{i} \Delta X_{t-i}+\varepsilon_{t} \\
& \Delta X_{t}=\beta_{1}+\delta \Delta X_{t-1}+\sum_{i=1}^{m} \alpha_{i} \Delta X_{t-i}+\varepsilon_{t} \\
& \Delta X=\beta_{1}+\beta_{2 t} \delta \Delta X_{t-1}+\sum_{i=1}^{m} \alpha_{i} \Delta X_{t-i}+\varepsilon_{t}
\end{aligned}
$$

Where, $\mathrm{m}$ is lag length

This study used Johansen method to establish the long run relationship between variables. In the short run there could be a possibility of disequilibrium relationship. Therefore the error term can be treated as a disequilibrium error which is used to tie the short run behavior of a variable to its long run behavior (Gujarati, 2004).

$$
\begin{aligned}
\Delta E_{t}= & \beta_{10}+\sum_{i=1}^{p} \beta_{11} \Delta M_{t-i}+\sum_{i=1}^{p} \beta_{12} \Delta E_{t-i}+\sum_{i=1}^{p} \beta_{13} \Delta E D_{t-i}+\sum_{i=1}^{p} \beta_{14} \Delta T B_{t-i} \\
& +\sum_{i=1}^{p} \beta_{15} \Delta I_{t-i}+\lambda_{i} \mu_{t-1}+\varepsilon_{1 t} \\
\Delta M_{t}= & \beta_{20}+\sum_{i=1}^{p} \beta_{21} \Delta M_{t-i}+\sum_{i=1}^{p} \beta_{22} \Delta E_{t-i}+\sum_{i=1}^{p} \beta_{23} \Delta E D_{t-i}+\sum_{i=1}^{p} \beta_{24} \Delta T B_{t-i} \\
& +\sum_{i=1}^{p} \beta_{25} \Delta I_{t-i}+\lambda_{i} \mu_{t-1}+\varepsilon_{2 t} \\
\Delta E D_{t}= & \beta_{30}+\sum_{i=1}^{p} \beta_{31} \Delta M_{t-i}+\sum_{i=1}^{p} \beta_{32} \Delta E_{t-i}+\sum_{i=1}^{p} \beta_{33} \Delta E D_{t-i}+\sum_{i=1}^{p} \beta_{34} \Delta T B_{t-i} \\
& +\sum_{i=1}^{p} \beta_{35} \Delta I_{t-i}+\lambda_{i} \mu_{t-1}+\varepsilon_{3 t} \\
\Delta T B_{t}= & \beta_{40}+\sum_{i=1}^{p} \beta_{41} \Delta M_{t-i}+\sum_{i=1}^{p} \beta_{42} \Delta E_{t-i}+\sum_{i=1}^{p} \beta_{43} \Delta E D_{t-i}+\sum_{i=1}^{p} \beta_{44} \Delta T B_{t-i} \\
& +\sum_{i=1}^{p} \beta_{45} \Delta I_{t-i}+\lambda_{i} \mu_{t-1}+\varepsilon_{4 t}
\end{aligned}
$$




$$
\begin{aligned}
\Delta I_{t}= & \beta_{50}+\sum_{i=1}^{p} \beta_{51} \Delta M_{t-i}+\sum_{i=1}^{p} \beta_{52} \Delta E_{t-i}+\sum_{i=1}^{p} \beta_{53} \Delta E D_{t-i}+\sum_{i=1}^{p} \beta_{54} \Delta T B_{t-i} \\
& +\sum_{i=1}^{p} \beta_{55} \Delta I_{t-i}+\lambda_{i} \mu_{t-1}+\varepsilon_{5 t}
\end{aligned}
$$

Pair wise granger causality was estimated using the following pair of regressions;

$$
\begin{aligned}
\Delta E_{t}= & \beta_{10}+\sum_{i=1}^{p} \beta_{11} \Delta M_{t-i}+\sum_{i=1}^{p} \beta_{12} \Delta E_{t-i}+\sum_{i=1}^{p} \beta_{13} \Delta E D_{t-i}+\sum_{i=1}^{p} \beta_{14} \Delta T B_{t-i} \\
& +\sum_{i=1}^{p} \beta_{15} \Delta I_{t-i}+\varepsilon_{1 t} \\
\Delta M_{t}= & \beta_{20}+\sum_{i=1}^{p} \beta_{21} \Delta M_{t-i}+\sum_{i=1}^{p} \beta_{22} \Delta E_{t-i}+\sum_{i=1}^{p} \beta_{23} \Delta E D_{t-i}+\sum_{i=1}^{p} \beta_{24} \Delta T B_{t-i} \\
& +\sum_{i=1}^{p} \beta_{25} \Delta I_{t-i}+\varepsilon_{2 t} \\
\Delta E D_{t}= & \beta_{30}+\sum_{i=1}^{p} \beta_{31} \Delta M_{t-i}+\sum_{i=1}^{p} \beta_{32} \Delta E_{t-i}+\sum_{i=1}^{p} \beta_{33} \Delta E D_{t-i}+\sum_{i=1}^{p} \beta_{34} \Delta T B_{t-i} \\
& +\sum_{i=1}^{p} \beta_{35} \Delta I_{t-i}+\varepsilon_{3 t} \\
\Delta T B_{t}= & \beta_{40}+\sum_{i=1}^{p} \beta_{41} \Delta M_{t-i}+\sum_{i=1}^{p} \beta_{42} \Delta E_{t-i}+\sum_{i=1}^{p} \beta_{43} \Delta E D_{t-i}+\sum_{i=1}^{p} \beta_{44} \Delta T B_{t-i} \\
& +\sum_{i=1}^{p} \beta_{45} \Delta I_{t-i}+\varepsilon_{4 t} \\
\Delta I_{t}=\beta_{50} & +\sum_{i=1}^{p} \beta_{51} \Delta M_{t-i}+\sum_{i=1}^{p} \beta_{52} \Delta E_{t-i}+\sum_{i=1}^{p} \beta_{53} \Delta E D_{t-i}+\sum_{i=1}^{p} \beta_{54} \Delta T B_{t-i} \\
& +\sum_{i=1}^{p} \beta_{55} \Delta I_{t-i}+\varepsilon_{5 t}
\end{aligned}
$$

Where it was assumed that the error terms $\mu \varepsilon_{1 t}, \mu \varepsilon_{2 t}, \varepsilon_{3 t}, \varepsilon_{4 t}$ and $\varepsilon_{5 t}$ are uncorrelated. The study involved testing the following hypothesis;

$H_{0}$ : No causality,

$H_{1}$ : Causality exists

\subsection{Empirical Results}

This study examined the relationship between money supply and real effective exchange rate in Kenya. External debt, trade balance, inflation were used as the intervening variables. 


\subsection{Trend Analysis}

\subsubsection{Trend of Real effective exchange Rate in Kenya}

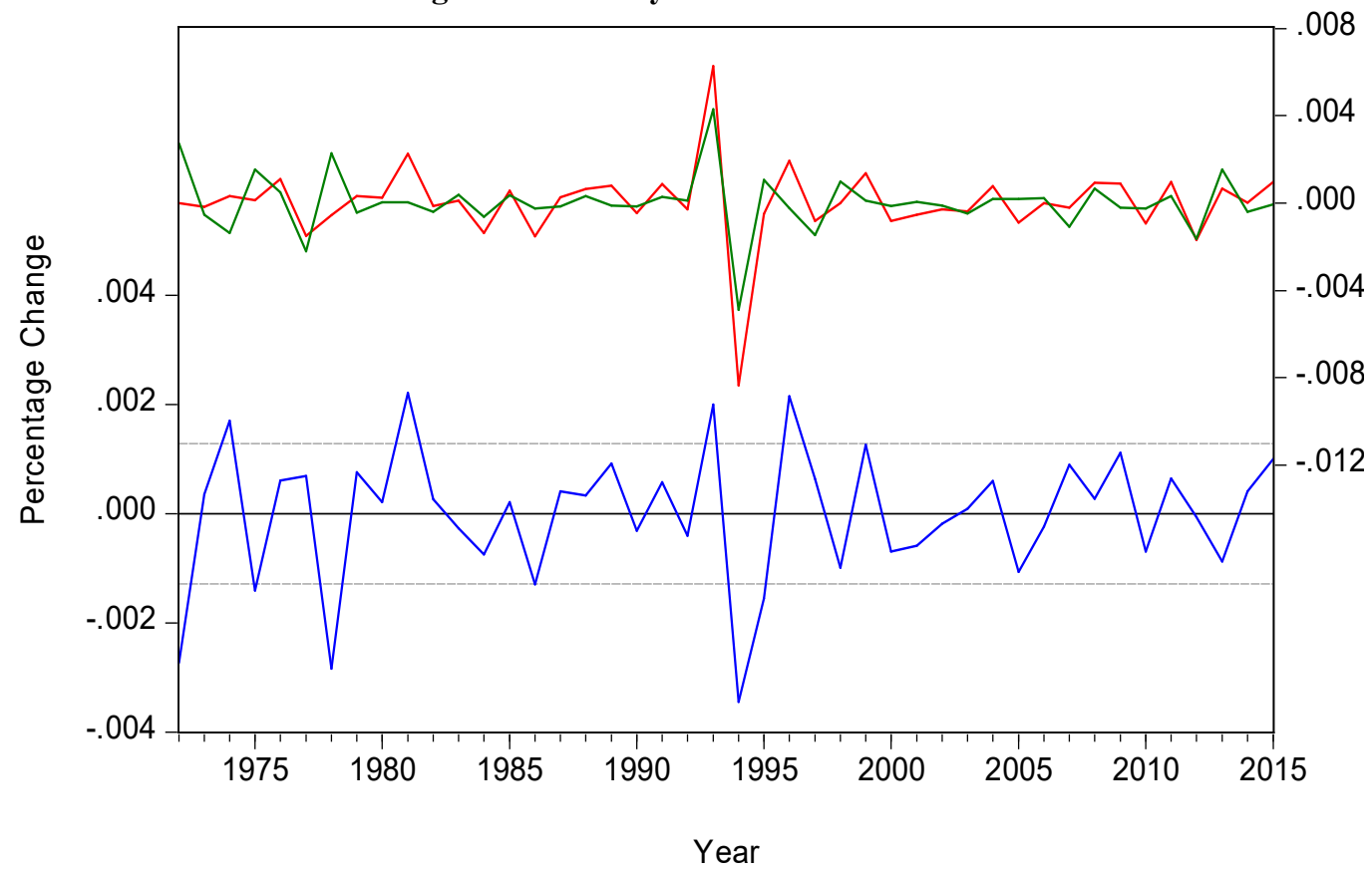

Figure 4.1: Real effective exchange rate fluctuations

Figure 4.1 above shows Kenya's real effective exchange rate trend for the period 1972-2015. Clearly as shown the Kenya shilling has been fluctuating against the US dollar from the year 1972 when Kenya adopted the crawling exchange rate regime to cushion the country against the 1970's oil price shocks. This was the same period of the collapse of the Bretton woods system because its pegged exchange rates could not be sustained in a new global financial environment in which international financial flows were continually growing and sometimes circumventing governments' official investment barriers (Makin, 2004). According to Ndung'u (2001), the Kenya government liberalized the financial, foreign exchange and goods market. This liberalization was steady from the adoption of the crawling peg exchange rate regime from the 1960s fixed exchange rate regime to the flexible regime of 1993 to date. Following the liberalization of the foreign exchange market, Kenya attained monetary independence to control inflationary pressures but lost the nominal anchor to tie domestic prices down and thus globalization effects were transmitted directly into the country. The exchange rate has been fluctuating significantly from the 1970's to date.

In 1972 the Kshs against the US dollar was 7.1429. A growth margin of about 2 points was experienced until 1982 when the shilling weakened against the dollar to a low of 10.9230. There was no course of alarm as this was within the CBK range. However, there was an alarming weakening shilling from 1982 to an all-time low of 58.0013 in the year 1993 forcing the country to adopt the flexible exchange rate where market forces were given room to prevail. There was a downward trend as the shilling appreciated to 56.0506 in 1994 and 51.4298 in 1995. However, this did not continue for long as the shilling started experiencing an upward trend from 1995 to a low of 79.139 in 2004 before strengthening to 67.3176 in 2007. This was followed by the 2008 global financial crisis which saw the Kenya shilling depreciate against all other major world currencies. This was also the same period Kenya was experiencing it worst political crisis after the 2007 disputed presidential elections (OECD, 2012). The value of the Kenya shilling weakened from 67.3176 in 2007 to 69.1753 in 2008 and to an all-time low of 98.1785 in 2015 with the month of July 2015 recording the worst ever figure of 108. These upward and downward trends in the value of the Kenya shilling indicate fluctuations which implies the instability of the Kenya shilling globally. 


\subsubsection{Trend of Money Supply in Kenya}

\section{MONEY SUPPLY}

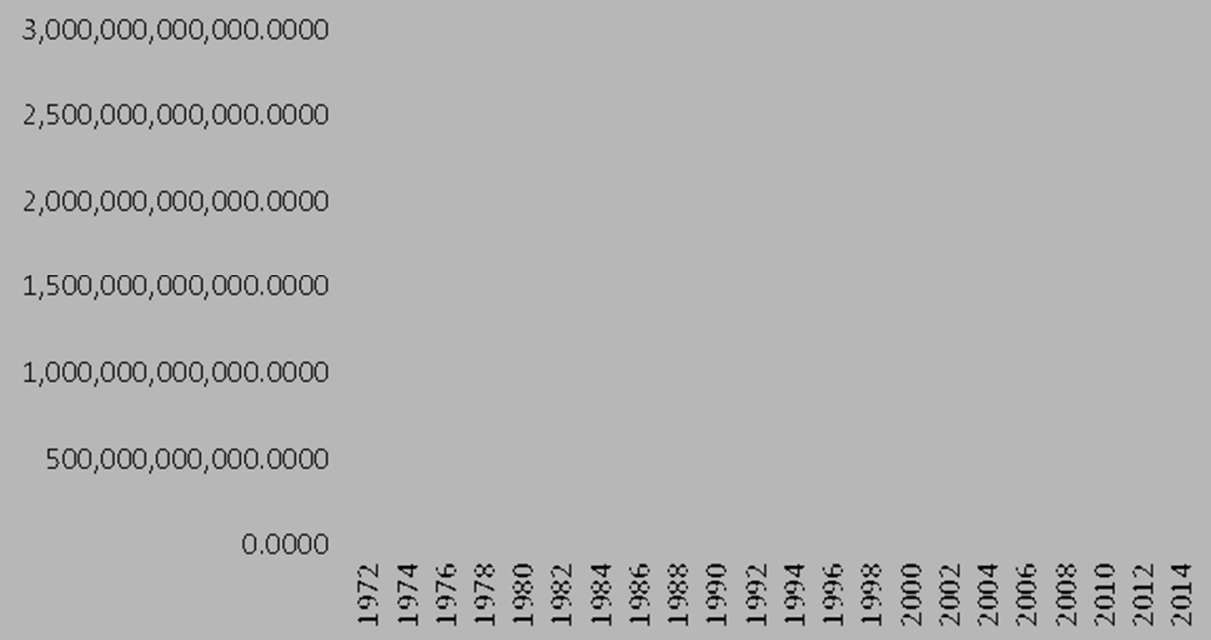

Figure 4.2: Money supply trend in Kenya (self-computation from excel sheet)

Figure 4.2 above shows Kenya's money supply trend for the period $1972-2015$. Clearly as depicted there is a steady increase in money supply from 4.295B in 1972 to $12.2 \mathrm{~B}$ in 1977, 16.13B in 1980. In 1986 money supply growth was more than $100 \%$ from $16.12 \mathrm{~B}$ in 1980 to $35.7 \mathrm{~B}$. This double increase is also shown in 1991 (69.4B) and 1992 (96.6B). Since then, the growth in money supply has been growing immensely to highs of 775B in 2007, $896 \mathrm{~B}$ in $2008,1.044 \mathrm{~T}$ in 2009 , and $1.277 \mathrm{~T}$ in 2010 and $2.65 \mathrm{~T}$ in 2015 . This clearly shows an ever increasing upward trend in money supply in Kenya. This was mainly attributed to the increased demand for money to finance various development projects in the country (Ndung'u, 2013).

\subsection{Correlation Analysis}

Table 4.1: Correlation matrix

Sample: 19702015

Included observations: 46

\begin{tabular}{|c|c|c|c|c|c|}
\hline $\begin{array}{l}\text { Correlation } \\
\text { Probability }\end{array}$ & E & ED & I & $\mathrm{M}$ & TB \\
\hline $\mathrm{E}$ & $\begin{array}{c}1.000000 \\
----\end{array}$ & & & & \\
\hline ED & $\begin{array}{r}0.207171 \\
(0.1671)\end{array}$ & $\begin{array}{r}1.000000 \\
----\end{array}$ & & & \\
\hline I & $\begin{array}{r}-0.020192 \\
(0.8940)\end{array}$ & $\begin{array}{r}0.079229 \\
(0.6007)\end{array}$ & $\begin{array}{c}1.000000 \\
----\end{array}$ & & \\
\hline $\mathrm{M}$ & $\begin{array}{r}0.761600 \\
(0.0000)\end{array}$ & $\begin{array}{r}0.559581 \\
(0.0001)\end{array}$ & $\begin{array}{r}-0.098187 \\
(0.5162)\end{array}$ & $\begin{array}{r}1.000000 \\
----\end{array}$ & \\
\hline TB & $\begin{array}{r}-0.683059 \\
(0.0000)\end{array}$ & $\begin{array}{r}-0.544308 \\
(0.0001)\end{array}$ & $\begin{array}{r}0.104989 \\
(0.4874)\end{array}$ & $\begin{array}{r}-0.984250 \\
(0.0000)\end{array}$ & $\begin{array}{r}1.000000 \\
----\end{array}$ \\
\hline
\end{tabular}

$N=45$ ( ) P-values

Based on the study's objective, there is a strong positive correlation between money supply and real effective exchange rate fluctuations in $\operatorname{Kenya}(r=0.7616)$. From the results in Table 4.1, the study therefore rejects the null hypothesis of no correlation between money supply and real effective exchange rate fluctuations in Kenya at $5 \%$ level of significance with the correlation between money supply and real effective exchange rate fluctuations being significant thus $r \neq 0$. These were in conformity with Saeed et al. (2012), in Pakistan, Papadopoulus and Zis (2000), in Greece, Wilson (2009), in USA, Karanja (2010) in the UK and Ndung'u (2000) in Kenya. These results however, contradict those found by Musa (1984), Hopper (1997), in USA, and Karanja (2010) in Kenya 
and Singapore who found a negative but significant relationship between money supply and exchange rate. The strong positive correlation indicated that a rise in money supply would cause changes to the Kenyan shilling. Given that various researchers had varied results on the correlation between money supply and real effective exchange rate fluctuations, our analysis establishes a strong significant positive correlation between money supply and real effective exchange rate fluctuations in Kenya.

\subsection{Stationarity Test}

To identify the time series property of stationarity for each of the variables, Augmented Dickey Fuller (ADF) test was performed on levels and first differences. The ADF test takes the form of equations (3.5), (3.6) and (3.7). This test examined the null hypothesis that the considered variable has a unit root (series non stationary) against the alternative hypothesis that the variable is stationary.

The results of ADF tests revealed that the real effective exchange rate is integrated of order 1, I (1) and nonstationary in levels (intercept, trend and intercept, none) and only become stationary after first differencing. For money supply, the ADF tests revealed that money supply is integrated of order 2, I (2) and is non-stationary at level (intercept, trend and intercept, none) and only becomes stationary after second differencing. The results are confirmed by Philip Pheron test.

\subsection{Cointegration and Vector Error Correction Mechanism 4.6.1 Cointegration Test Results}

Having determined that the variables of real effective exchange rate is integrated of order 1, I (1), money supply, external debt and trade balance integrated of order 2, I (2) and inflation is integrated of order 0 , I (0), this study established cointegration between money supply, external debt, trade balance and inflation and real effective exchange rate fluctuations in Kenya. To achieve this, the researcher performed the Johansen cointegration test to establish whether the variables in question are cointegrated using two likelihood ratio tests namely; the trace test and maximum eigenvalue test. Analysis of data was based on the null hypothesis of no cointegration in line with the objectives of this study.

The results indicate that both the trace test and maximum eigenvalue test in the Johansen procedure each detected 5 and 1 cointegrating vectors respectively, thus the study rejects the null hypothesis of no cointegration at $5 \%$ level of significance.

From the Johansen procedure results, model (3.2) becomes the cointegrating equation hence expressed as;

$$
\varepsilon_{t}-7.136329 M_{t}+2.406183 E D_{t}-0.295155 T B_{t}-0.167837 I_{t}
$$

Making exchange rate the subject, equation 4.1 becomes:

$$
\varepsilon_{t}=7.136329 M_{t}-2.406183 E D_{t}+0.295155 T B_{t}+0.167837 I_{t}
$$

Basing on the objective of the study, rejection of the null hypothesis of no cointegration at 5\% significance level among the variables implies that the variables of money supply and real effective exchange rate fluctuations in Kenya have a significant positive (equation 4.2) long run relationship that conforms to a priori expectation. This result is in conformity with Ndung'u (2000) in Kenya. Saeed et al. (2012), in Pakistan, Papadopoulus and Zis (2000), in Greece and Wilson (2009), in USA found. The results contradict those of Karanja (2010), in Kenya and Singapore who found that money supply had a negative but significant relationship with real effective exchange rate. Despite the varied results by various researchers, this finding of a significant positive long relationship between money supply and real effective exchange rate fluctuations in Kenya implies that money supply affects real effective exchange rate in the long run. Thus, a percentage increase in the level of money supply depreciates the Kenyan shilling by $7.1363 \%$.

\subsubsection{Vector Error Correction Model (VECM)}

Following Granger representation theorem which states that if two (or more) variables $\mathrm{Y}$ and X(s) are cointegrated, then the relationship between (or among) them can be expressed as error correction mechanism. Existence of cointegration among the variables of the model which we established necessitated the need for the VECM of the form (3.8), (3.9), (3.10), (3.11), and (3.12) to capture the short run dynamics of the model. The equilibrium error term $\mu_{t-1}$ corrects the disequilibrium and guides the variables $E_{t}, M_{t}, E D_{t}, T B_{t}$ and $I_{t}$ to restore back to equilibrium.

The results the ECM model by examining the F- statistics and the $R^{2}$ indicate that the variables in VECM significantly explained short-run changes in $E t$ (real effective exchange rate) at $5 \%$ level of significant accounting for $75.84 \%$. All the other variables in VECM also significantly explained short-run changes at $5 \%$ level of significance account for $75.48 \%$ for $M_{t}$ (money supply), 79.84\% for $E D_{t}$ (external debt), 86.25\% for $T B_{t}$ (trade balance) and $93.71 \%$ for ${ }_{t}$ (inflation rate). From the results in table 4.6 models (3.8), (3.9), (3.10), 
(3.11), and (3.12) are represented as models (4.3), (4.4), (4.5), (4.6) and (4.7) respectively with 3 lags and tstatistics in parentheses.

$$
\begin{aligned}
& \Delta E_{t}=\underset{[-0.0702]}{0.0000231-0.3298 \Delta M_{t-1}-0.6664 \Delta M_{t-2}-0.0017 \Delta M_{t-3}}-0.7806 \Delta E_{t-1}-0.3475 \Delta E_{t-2} \\
& -0.1390 \Delta E_{t-3}+0.2662 \Delta E D_{t-1}+0.2252 \Delta E D_{t-2}+0.2458 \Delta E D_{t-3}-0.01340 \Delta T B_{t-1} \\
& +\underset{[0.4033]}{0.0091 \Delta T B_{t-2}} \\
& \underset{[0.5785]}{+0.0077 \Delta T B_{t-3}}-\underset{[-1.4607]}{0.0150 \Delta I_{t-1}}-\underset{[-1.3960]}{0.0091 \Delta I_{t-2}}-\underset{[-0.6040]}{0.0017 \Delta I_{t-3}}-0.1142 \Delta \mu_{t-1}
\end{aligned}
$$

The coefficients of the error correction term $\mu_{t-1}$ for the VECM1 (4.3) with economic real effective exchange rate fluctuations $\left(\Delta E_{t}\right)$ as the dependent variable has the correct sign which conform to economic a priori expectation i.e. negative and statistically significant at $5 \%$ level of significance (validating the existence of long run relationship among money supply, external debt, trade balance, inflation and real effective exchange rate fluctuations in Kenya. This implies that the vector of real effective exchange rate fluctuations $\left(E_{t}\right)$ is error correcting i.e. $-11.4179 \%$, of equilibrium error for real effective exchange rate fluctuations will be corrected in the next period (annually). This explains that real effective exchange rate fluctuations in Kenya adjust significantly to short run disequilibrium (shocks) caused by changes in money supply, external debt, trade balance and inflation.

Results VECM clearly indicate that while money supply, trade balance and inflation rate have a significant positive influence on Kenya's real effective exchange rate fluctuations in the long run, in the short run as depicted by VECM1 money supply and past values of real effective exchange rate fluctuations has an insignificant negative effect on economic real effective exchange rate fluctuations in Kenya at lag 1,2 and 3 whereas trade balance has an insignificant negative effect evident at lag 1 and insignificant positive effect at lag 2 and 3 on real effective exchange rate fluctuations and inflation rate has an insignificant negative effect on real effective exchange rate fluctuations in Kenya at both lag 1, 2 and 3. The $-0.3298,-0.664,-0.4484,-0.0140,-0.0150,-0.0091$ and -0.0017 coefficients of $M(-1), M(-2), M(-3), T B(-1), T B(-2), T B(-3), I(-1), I(-2)$ and $I(-3)$ respectively imply that in the short run, a unit increase in money supply, trade balance and inflation rate causes depreciation to the Kenyan shilling in the short run by $0.3298,0.664,0.4484,0.0140,0.0150,0.0091$ and 0.0017 units respectively. The constant $(-0.0000231)$ which represents the short run total factor productivity is negative and statistically insignificant.

\subsection{Residual Diagnostic Tests}

The study employed second order tests or econometric tests which include normality, serial correlation, and multicollinearity and heteroscedasticity tests to ascertain that the assumptions of regression analysis with regard to residuals and the correlation between explanatory variables are satisfied.

\subsubsection{Normality Test}

Normality test is carried out to verify if the error term is normally distributed. The study employed Jacque -Bera (JB) test to test for normality. The results in Figure 4.1 below show that the null hypothesis that residuals are normal distributed is not rejected. The $J B-$ statistic $=0.026980$ and from the chi-square distribution table at $5 \%$ level of significance, the critical $\chi^{2}(2 d f)=5.99147$. This implies that $J B-$ statistic $<\chi^{2}(2 d f)$, thus we do not reject the null hypothesis that residuals are normally distributed at $5 \%$ level of significance. 


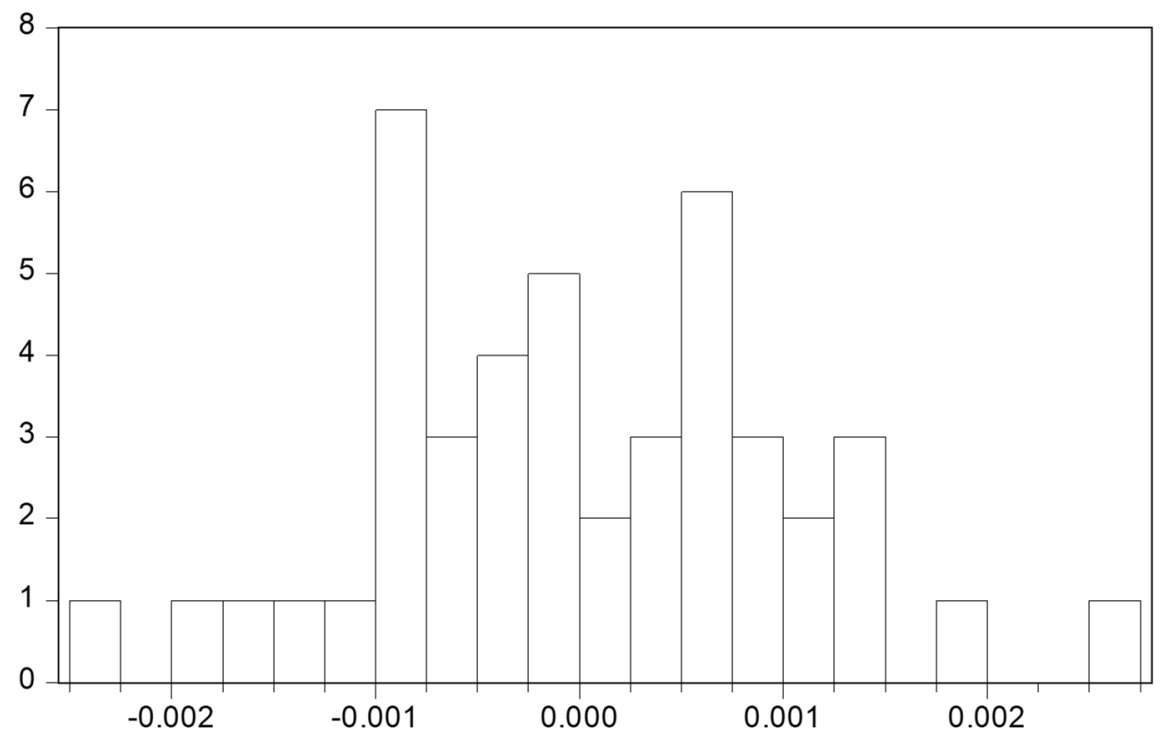

\section{Series: Residuals \\ Sample 19712015 \\ Observations 45}

Mean

Median

$1.64 \mathrm{e}-19$

Maximum

$-8.85 e-05$

Minimum

0.002587

Std. Dev.

Skewness

0.001014

Kurtosis

0.050704

Jarque-Bera

3.064075

Probability

Figure 4.1: Normality test results.

\subsubsection{Autocorrelation Test}

The Breusch- Godfrey serial correlation LM test was employed to test for serial correlation. Table 4.2 results indicate that the null hypothesis of no serial correlation is not rejected at $5 \%$ level of significance thus, the residuals are not correlated.

Table 4.2: Residual Serial Correlation LM Test

VEC Residual Serial Correlation LM Tests

Null Hypothesis: no serial correlation at lag order $\mathrm{h}$

Sample: 19722015

Included observations: 40

\begin{tabular}{ccc}
\hline \hline Lags & LM-Stat & Prob \\
\hline \hline 1 & 20.12285 & 0.7404 \\
\hline \hline
\end{tabular}

\subsubsection{Multicollinearity}

This study involved the use of Variance Inflation Factor (VIF) to test for multicollinearity. The results in Table 4.3 clearly indicate all the VIF are less than 10. This implies that none of the variables is highly collinear.

Table 4.3: Variance Inflation Factors

Sample: 19712015

Included observations: 45

\begin{tabular}{cccc}
\hline \hline Variable & $\begin{array}{c}\text { Coefficient } \\
\text { Variance }\end{array}$ & $\begin{array}{c}\text { Uncentered } \\
\text { VIF }\end{array}$ & $\begin{array}{c}\text { Centered } \\
\text { VIF }\end{array}$ \\
\hline \hline C & $1.09 \mathrm{E}-07$ & 4.327733 & NA \\
ED & 0.001253 & 1.126699 & 1.021634 \\
I & $2.82 \mathrm{E}-06$ & 1.033354 & 1.033143 \\
TB & 0.029422 & 4.142800 & 1.063465 \\
\hline \hline
\end{tabular}

Note: if VIF is greater than 10, the variables are highly collinear

\subsubsection{Heteroscedasticity Test}

The study employed White's General heteroscedasticity Test to test for heteroscedasticity. Results depicted in Table 4.4 show that there is no heteroscedasticity. This implies that we do not reject the null hypothesis of no heteroscedasticity (homoscedasticity) at $5 \%$ level of significance thus a constant variance for the residuals. 
Table 4.4: Residual Heteroscedasticity Test Result

VEC Residual Heteroskedasticity Tests: No Cross Terms (only levels and squares)

Sample: 19722015

Included observations: 40

Joint test:

\begin{tabular}{ccc}
\hline \hline Chi-sq & df & Prob. \\
\hline \hline 464.4052 & 480 & 0.6870 \\
\hline \hline
\end{tabular}

\subsection{Granger Causality Test}

Cointegration gives signal that there is possibility of causality but does not show direction of causality. This study examined causality linkage between exchange rate, money supply, external debt, trade balance and inflation in Kenya by estimating five VAR models (3.13), (3.14), (3.15), 3.16 and (3.17). Data analysis was based on the null hypothesis of no causality and in line with the objectives of the study. The test involved 3 lags based on the Akaike Information Criterion to ensure consistency with the criterion used in the determination of lag length right from unit root test through cointegration and vector error correction tests.

Table 4.5: Pairwise Granger Causality Tests

Sample: 19722015

Lags: 3

\begin{tabular}{llrr}
\hline \hline Null Hypothesis: & Obs & F-Statistic & Prob. \\
\hline \hline M does not Granger Cause E & 41 & 5.16035 & $0.0039^{*}$ \\
E does not Granger Cause M & & 0.26436 & 0.8506 \\
\hline \hline & & & \\
ED does not Granger Cause E & 41 & 3.05235 & $0.0121^{*}$ \\
E does not Granger Cause ED & & 0.26138 & 0.8527 \\
\hline \hline TB does not Granger Cause E & 41 & 2.85970 & $0.0488^{*}$ \\
E does not Granger Cause TB & & 1.15853 & 0.3398 \\
\hline \hline I does not Granger Cause E & 41 & 3.17649 & $0.0096^{*}$ \\
E does not Granger Cause I & & 4.94563 & $0.0059^{*}$ \\
\hline
\end{tabular}

The results summarized in Table 4.5 indicate that unidirectional causality exists between money supply and real effective exchange rate fluctuations $\left(M_{t} \rightarrow E_{t}\right)$. This implies that the null hypothesis of no causality is rejected for the relationship between money supply and real effective exchange rate fluctuations in Kenya. The unidirectional causality running from money supply to real effective exchange rate fluctuations in Kenya conforms to a priori expectation and is significant at $5 \%$ level of significance. The finding of causality from money supply to real effective exchange rate fluctuations in Kenya implies that money supply affects real effective exchange rate fluctuations in Kenya. 


\subsection{Impulse Response}

Response of $\mathrm{E}$ to $\mathrm{M}$

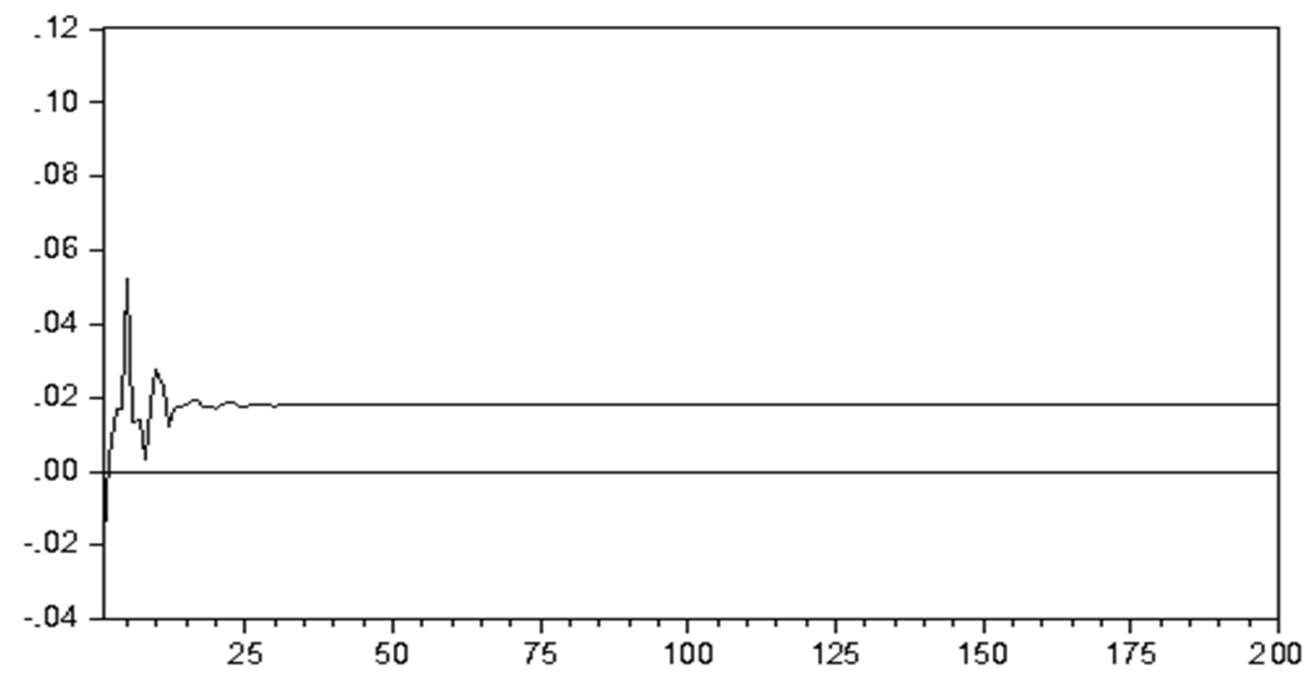

Figure 4.2: Response of Real Effective Exchange Rate Fluctuations to Money Supply

The objective of this study was to examine the relationship between money supply and real effective exchange rate fluctuations in Kenya. The response to one standard deviation innovation to money supply as depicted in Figure 4.2 resulted in explosive positive effect on real effective exchange rate up to the $5^{\text {th }}$ year and dampened by the $25^{\text {th }}$ year after which the effect fizzled out.

\subsection{Variance Decomposition Analysis}

The study employed variance decomposition to examine the proportion of the variance in real effective exchange rate fluctuations that was due to own and each of the independent variables variations over time in line with objectives of the study. It was noted that the larger proportion of variance in inflation was due to its own shock at $100 \%$ in the first year and reduced to $73.70 \%$ by the $12^{\text {th }}$ year as depicted in Table 4.12 .

Table 4.6: Variance Decomposition

Variance Decomposition of E:

\begin{tabular}{ccccccc} 
Period & S.E. & E & ED & I & M & TB \\
\hline \hline 1 & 0.169290 & 100.0000 & 0.000000 & 0.000000 & 0.000000 & 0.000000 \\
2 & 0.189343 & 92.44552 & 0.129666 & 0.082887 & 2.518982 & 4.822948 \\
3 & 0.209291 & 82.80885 & 1.068482 & 1.321318 & 8.143393 & 6.657960 \\
4 & 0.224889 & 77.58841 & 5.929840 & 1.290648 & 8.141921 & 7.049185 \\
5 & 0.248718 & 72.31463 & 10.77413 & 1.773311 & 8.706947 & 6.430979 \\
6 & 0.253947 & 71.95106 & 10.83403 & 2.122856 & 8.895050 & 6.197001 \\
7 & 0.265809 & 72.88158 & 10.17362 & 2.013775 & 9.183654 & 5.747368 \\
8 & 0.274049 & 72.55495 & 10.10240 & 1.986096 & 9.846023 & 5.510535 \\
9 & 0.284734 & 73.28634 & 9.374215 & 2.332814 & 9.726121 & 5.280511 \\
10 & 0.292969 & 73.46837 & 9.110452 & 2.225021 & 9.965506 & 5.230648 \\
11 & 0.302638 & 73.61110 & 8.605601 & 2.271947 & 10.50584 & 5.005512 \\
12 & 0.308830 & 73.70160 & 8.309053 & 2.402418 & 10.69432 & 4.892605 \\
\hline \hline
\end{tabular}

The objective of this study was to examine the relationship between money supply and real effective exchange rate fluctuations in Kenya. Tables 4.6 test results indicated that in the first period the variation in real effective exchange rate in Kenya resulting from money supply, external debt, trade balance and inflation was $0 \%$. The influence of money supply on variation in real effective exchange rate in Kenya increased continuously with increase in forecasting time from the $2^{\text {nd }}$ period at $2.52 \%$ up to the $12^{\text {th }}$ period at $10.69 \%$.

The findings implied that the money supply is a determinant of real effective exchange rate fluctuations in Kenya. The study therefore rejected the null hypothesis of no relationship between money supply and real effective exchange rate fluctuations in Kenya. This was in conformity to the balance of payments theory hence the model specification used. 


\subsection{Conclusion}

The objective of this study was to examine the relationship between money supply and real effective exchange rate fluctuations in Kenya. Analysis of data on this objective was based on the null hypothesis of no relationship between money supply and real effective exchange rate fluctuations in Kenya. First, the correlation coefficients show that there is a strong positive significant correlation $r=0.7661$ ) at $5 \%$ significance level between money supply and real effective exchange rate fluctuations in Kenya. Secondly, the trace test and maximum eigenvalue test in the Johansen procedure detected five (5) and one (1) cointegrating vectors at 5\% level of significance implying that the variables of money supply and real effective exchange rate fluctuations in Kenya have a significant positive long run relationship that conforms to economic a priori. Thirdly, the Vector Error Correction Model results indicate that in the short- run money supply has an insignificant negative relationship with real effective exchange rate fluctuations at 5\% level of significance in Kenya. From these results the study therefore rejects the null hypothesis of no relationship between money supply and real effective exchange rate fluctuations in Kenya at $5 \%$ level of significance.

In conclusion, there is a significant positive long run relationship between; money supply and real effective exchange rate fluctuations in Kenya. Owing to these results it can also be concluded that the balance of payments theory of exchange rate determination is applicable in Kenya as it can clearly be seen that an increasing money supply depreciates the Kenya shilling and the CBK has to sell Kenya shilling denominated bonds to reduce money supply so as to appreciate the shilling.

\subsection{Recommendation}

Based on the analysis and findings in this study, it is suggested that a proper monetary policy framework should be instituted by the government of Kenya through the Central Bank that will control the supply of money in Kenya despite the ever growing demand of money. Credit control measures like the central bank rate, overnight lending and the cash reserve ratios should be adequately enhanced and controlled by the CBK to avoid unnecessary injection of money into the economy.

\section{References}

Edward, S. (1994). Real and monetary determinants of the real effective exchange rate behaviour:Theory and evidence from developing countries. Washington D C: Institute of International Economics.

Gujarati, D. N. (2004). Basic econometrics (4th ed.). London, United Kingdom: The Mcgraw-Hill Companies.

Hopper, P. G. (1997). What determines the exchange rate:Economic factors or market sentiment? Business Review, 17-29.

Karanja, W. (2010). Determinants of echange rate and exchange rate volatility: A comparative study of selected countries. Nairobi: Strathmore Univerity.

Kothari, C. R. (2004). Research methodoly: Methods and techniques. Nairobi: New Age International Publishers.

Miller, C. N. (1986). A general approach to the balance of payments and exchange rate. Journal of International Economic Integration , 1 (1), 85-122.

Mussa., L. (1984). The theory of exchange rate determination. In J. F. Bilson., \& R. C. Marston., Exchange rate theory and practice (pp. 13-78). Chicago: University of Chicago Press.

Musyoki, D., Pokhariyal, G. P., \& Pundo, M. (2012). Real effective exchange rate equilibrium and misalignment in Kenya. Journal of Business Studies Quarterly, 3 (4), 24-42.

Ndung'u, N. S. (2000). The exchange rate and the interest rate differential in Kenya: A monetary and fiscal dilemma. Nairobi: Kenya Institute for Public Policy Research and Analysis.

Ndung'u, N. S. (2001). Liberalization of the foreign exchange market in Kenya and short term capital flows problem. nairobi: African Economic Research Consortium.

Ndungu, N. S. (February, 2000). Monetary and exchange rate policy in Kenya. Nairobi: African Economic Research Consortium (Aerc).

Otuori, O. H. (2013). Influence of exchange rate determinants on the performance of commercial banks in Kenya. European Journal of Management Sciences and Economics , 1 (2), 86-98.

Papadopouls, A. P., \& Zis, G. (2000). A monetary analysis of the Drachma/ECU exchange rate determination. Empirical Economics , 25, 653-663.

Saeed, A., Rehmat, U. A., Sial, M. H., \& Sher, F. (2012). An econometric analysis of determinants of exchange rate in Pakistan. International Journal of Business and Social Science , 3 (6), 184-196.

WorldBank. (2013). Time to shift gears: Accelerating growth and poverty reduction in the new Kenya (8 ed.). Nairobi: World Bank. 